\title{
PUBLIC POLICY SEBAGAI SYARAT PENGAKUAN DAN PELAKSANAAN PUTUSAN ARBITRASE INTERNASIONAL
}

\author{
Supeno ${ }^{1}$ \\ Fakultas Hukum Universitas Batanghari Jalan Slamet Riyadi Broni Kota Jambi \\ Telpon: (0741) 65351 \\ msasyabani@gmail.com
}

\begin{abstract}
Abstrak
Faktor kepastian hukum dalam penyelesaian sengketa suatu perkara merupakan tujuan yang ingin dicapai oleh para pencari keadilan termasuk penyelesaian sengketa bisis melalui badan arbitrase, akan tetapi Undang-Undang Nomor 30 Tahu 1999 masih mengisyaratkan bahwa penyelesaian sengketa yang sudah diputus oleh badan arbitrase internasional harus mendapatkan pengakuan dari negara di mana putusan tersebut akan dilaksanakan dan salah satu alasan tidak diakuinya suatu putusan arbitrase internasional karena putusan bertentangan dengan ketertiban umum (public policy) sehingga ketentuan ini dapat menimbulkan ketidakpastian hukum. Tipe yang digunakan adalah yuridis normatif dengan menggunakan pendekatan perundang-undangan. Tujuan dari penelitian ini adalah untuk memberikan sumbangan pemikiran dalam melakukan upaya perbaikan klausul tentang pengakuan dan pelaksanaan putusan arbitrase internasional dalam upaya memberikan kepastia hukum dalam penyelesaian sengketa yang diselesaikan melalui arbitrase internasional.
\end{abstract}

Kata kunci : Putusan arbitrase, pengakuan, public policy

\begin{abstract}
Legal certainty factors in the resolution of a dispute a matter is a goal to be achieved by the seekers of justice including the resolution of disputes through arbitration agency bisis, Act No. 30 of 1999 still Know hinted that dispute resolution which was already decided by the international arbitration body should get the recognition from the country where the verdict will be implemented and one of the reasons not to use an international arbitration ruling due the verdict contrary to the public order (public policy) so that this provision may give rise to legal uncertainty. The type used is the juridical normative approach with the use of legislation. The purpose of this research is to contribute to the thought of doing a repair effort clause about the recognition and implementation of the ruling of international arbitration in an attempt to give the kepastia law in the settlement of disputes resolved through international arbitration.
\end{abstract}

Keywords: Award, recognition, public policy

\section{PENDAHULUAN}

Setelah selesainya perang dunia kedua timbul kesadaran bahwa tidak semua kebutuhan masyarakat dapat disediakan oleh suatu Negara oleh karena itu muncul suatu pemikiran bahwa perlu adanya suatu hubungan yang luas untuk memenuhi kebutuhan tersebut, hubungan tersebut tidah hanya terbatas pada hubungan bilateral dan regional saja akan tetapi hubungan yang lebih luas. Pada tanggal 23 Oktober tahun 1947 sebanyak 23 negara menyiapkan bahan tentang piagam

${ }^{1}$ Dosen Fakultas Hukum Universitas Batanghari Jambi 
organisasi perdagangan internasional menandatangani perjanjian umum tentang tariff dan perdagangan (General Agreement Tarrif and Trade/GATT). Dalam perkembangan selanjutnya pada tanggal 15 April 1994 para menteri perdagangan di Marrakesh Maroko menyetujui pembentukan organisasi perdagangan dunia (World Trade Organization/WTO). Tujuan didirikannya WTO sebagaimana yang dimuat dalam mukadimah pendiriannya adalah:

Bahwa hubungan-hubungan perdagangan dan kegiatan ekonomi Negaranegara anggota harus dilaksanakan dengan maksud untuk meningkatkan standar hidup, menjamin lapangan kerja sepenuhnya, peningkatan penghasilan nyata, memperluas produksi dan perdagangan barang dan jasa, dengan penggunaan optimal sumber-sumber daya dunia sesuai dengan tujuan pembangunan berkelanjutan. Juga mengusahakan perlindungan lingkungan hidup dan meningkatkan cara-cara pelaksanaannya dengan caracara yang sesuai dengan kebutuhan masing-masing Negara yang berada pada tingkat pembangunan ekonomi yang berbeda. Dalam mengejar tujuantujuan ini diakui adanya suatu kebutuhan akan langkah-langkah positif untuk menjamin agar supaya Negara berkembang, teristimewa yang paling terbelakang, mendapatkan bagian dari pertumbuhan perdagangan internasional sesuai dengan kebutuhan pembangunan ekonominya. ${ }^{2}$

Tujuan didirikannya WTO untuk meningkatkan standar hidup, menciptakan lapangan kerja, meningkatkan penghasilan, memperluas produksi dan perdagangan barang dan jasa, mengusahakan perlindungan lingkungan hidup. Salah satu tujuan yang penting adalah memperluas produksi dan perdagangan barang dan jasa.

Perdagangan merupakan merupakan faktor yang penting dalam upaya meningkatkan kemajuan ekonomi rakyat, demikian pula untuk meningkatkan ekonomi suatu Negara maka perdagangan antar Negara merupakan salah satu upaya untuk mencapai tujuan tersebut. Perdagangan antar Negara menjadi alternatif positif untuk mencapai kemakmuran suatu Negara karena sebelum meletusnya perang dua ke-dua dalam untuk mencapai kemakmuran suatu Negara melakukan ekspansi terhadap Negara lain yang bukan hanya merugikan Negara yang diekspansi tetapi juga bagi Negara yang melakukan ekspansi karena selain korban jiwa juga mengalami kerugian secara materi.

Tujuan dasar dari perdagangan international adalah untuk membawa keuntungan bagi kedua Negara yang melakukan hubungan dagang tersebut. Dengan adanya kesepakatan yang tertuang dalam General Agreement Tariff and Trade (GATT) dilanjutkan dengan terbentuknya World Trade Organization (WTO) yaitu organisasi perdagangan dunia maka perdagangan antar Negara bukan hanya terbatas dilakukan antar dua Negara akan tetapi perdangan bersifat global dan mencakup banyak Negara yaitu bagi Negara yang menandatangani kesepakatan tersebut dan Negara yang meratifikasi kesepakatan GATT termasuk Indonesia melalui Undang-Undang Nomor 7 Tahun 1994.

Kegiatan perdagangan tidak terlepas dari kegiatan transaksi, dalam hubungan ekonomi internasional dibedakan 5 (lima) kategori utama transaksi internasional yaitu:

${ }^{2}$ Hatta, Perdagangan Internasional dalam Sistem GATT dan WTO, Refika Aditama, Bandung, 2006, hal. 88 . 
1. Pergerakan barang-barang secara lintas batas Negara (international movement of goods) atau lazim disebut perdagangan internasional di bidang barang.

2. Pergerakan jasa-jasa secara lintas batas Negara, atau biasa disebut perdagangan jasa (invisible trade).

3. Pergerakan orang-orang yang melitasi batas Negara (international movement of persons), misalnya kebebasan bekerja bagi orang atau badan hokum di Negara lain.

4. Pembayaran internasional dalam transaksi-transaksi ekonomi tersebut yang biasanya menyangkut tukar menukar mata uang sing (foreign exchange transactions). ${ }^{3}$

Transaksi perdagangan internasional adalah transaksi yang melibatkan kepentingan lebih dari satu sistem hukum Negara yang berbeda, dalam transaksi pada umumnya setiap Negara cenderung memilih agar kontrak yang dibuat tunduk pada hukum negaranya.

Untuk menghindari benturan-benturan tersebut dalam perdagangan internasional dapat dilakukan upaya sebagai berikut :

1. Dengan pembuatan konvensi-konvensi internasional

2. Penyelesaian lewat hukum perdata internasional

3. Penyelesaian lewat pengaturan para pihak dalam kontrak ${ }^{4}$

Penyelesaian lewat pengaturan para pihak yang dituangkan dalam kontrak adalah penting karena dalam kontrak tersebut dapat disepakati jika terjadi permasalahan hukum Negara mana yang akan dipilih atau dengan cara penyelesaian bagaimana yang akan ditempuh, kesepakatan menjadi hukum bagi kedua belah pihak. Jika dalam kontrak disepakati akan diselesaikan menggunakan sistem hukum suatu Negara maka penyelesaiannya akan dilakukan berdasarkan hukum Negara tersebut, ada juga kesepakatan yang menetapkan bahwa penyelesaian akan melalui badan arbitrase internasional.

Arbitrase adalah suatu proses di mana dua pihak atau lebih menyerahkan sengketa mereka kepada satu orang atau lebih yang imparsial untuk memperoleh suatu putusan yang final dan mengikat, ${ }^{5}$ berarti bahwa jika terjadi suatu sengketa antara beberapa pihak yang terikat dalam suatu perjanjian bisnis para pihak menyerahkan permasalahan tersebut kepada seseorang yang professional atau kepada suatu badan arbitrase untuk menyelesaikan permasalahan tersebut untuk mendapatkan keputusan yang final dan binding.

Untuk membicarakan lebih lanjut tentang arbitrase maka perlu diketahui terlebih dahulu tentang dasar hukum arbitrase dalam tata hukum di Indonesia yaitu:

1. Pasal 377 HIR yang mengatur bahwa jika orang Indonesia dan orang timur asing menghendaki perselisihan mereka diputuskan oleh juru pisah, maka merek wajib menuruti peraturan pengadilan perkara yang berlaku bagi bangsa Eropa

2. Pasal 615-651 Rv (Reglement of the Bergelijke Rechsvordering) yang mengatur tentang persetujuan arbitrase dan pengangkatan arbiter, pemeriksaan

\footnotetext{
${ }^{3}$ Huala Adolf, Hukum Ekonomi Internasional, Raja Grafindo, Jakarta, 2005, hal. 5-6.

${ }^{4}$ Munir Fuadi, Pengantar Hukum Bisnis, Citra Aditya Bakti, Bandung, 2002, hal.284.

${ }^{5}$ Gatot Soemartono, Arbitrase dan mediasi di Indonesia, Gramedia Pustaka Utama, Jakarta,
} 2006, hal. 24 
di muka arbitrase, putusan arbitrase, upaya-upaya terhadap putusan arbitrase, berakhirnya acara arbitrase.

3. UU Nomor 30 Tahun 1999 Tentang Arbitrase dan Alternatif Penyelesaian Sengketa (APS)

Menurut Pasal 1 angka 1 UU Nomor 30 Tahun 1999 menyatakan bahwa arbitrase adalah cara penyelesaian suatu perkara perdata di luar pengadilan umum yang didasarkan pada perjanjian arbitrase yang dibuat secara tertulis oleh para pihak yang bersengketa. Dengan demikian arbitrase adalah penyelesaian sengketa di luar pengadilan umum yang memiliki jurisdiksi sendiri, yang memiliki perbedaan yang sangat signifikan dengan cara penyelesaian sengketa melalui peradilan umum.

Penyelesaikan sengketa dengan menggunakan jalur arbitrase sebagai salah satu alternatif penyelesaian sengketa bidang perdagangan memiliki keunggulan dan kelebihan dibandingkan dengan penyelesaian sengketa melalui lembaga peradilan yang ada, kelebihan dari arbitrase tersebut adalah:

1. Proses cepat, karena tidak mempunyai upaya hukum lainnya sebagaimana yang berlaku dalam system peradilan umum yang ada, dengan proses yang cepat tersebut para pihak tidak terkuras tenaga, fikiran dan financial dalam suatu perkara yang justru akan mengkibatkan kerugian bagi para pihak yang bersengketa;

2. Para pihak diberi kebebasan untuk memilih arbiter yang disepakati sehingga terjamin independensinya;

3. Para pihak dapat menentukan pilihan hukum untuk menyelesaikan masalahnya, proses serta tempat penyelenggaraan arbitrase;

4. Pemeriksaan oleh para ahli, yang menjadi arbiter adalah orang yang benarbenar ahli dan menguasai permasalahan yang disengketkan sehingga kualitas putusan yang dijatuhkan dapat dipertanggungjawabkan;

5. Kerahasiaan sengketa para pihak dijamin karena proses penyelesaiannya dilaksanakan secara tertutup sehingga kepentingan-kepentingan para pihak dapat dilindungi;

6. Putusan arbitrase merupakan keputusan akhir (final) dan mengikat (binding) sebagaimana yang diatur dalam pasal 35 ayat (1) Model Arbitrase UNCITRAL (United Nation International Trade Law): an arbitral award, irrespective of the country in which it was made, shall be recognized as binding and shall be enforce, demikian juga ditegaskan dalam Pasal 53 UU Nomor 30 Tahun 1999 Tentang Arbitrase dan Alternatif Penyelesaian Sengketa (APS) dinyatakan bahwa terhadap putusan arbitrase tidak dapat dilakukan perlawanan atau upaya hukum apapun, dan dalam pasal 60 dinyatakan bahwa: Putusan arbitrase bersifat final dan mempunyai kekuatan hukum tetap dan mengikat para pihak.

Menurut Witanto dalam bukunya Hukum acara mediasi menyatakan bahwa:

Arbitrase merupakan bagian dari "kompetensi absolute" karena sifatnya memaksa. Jika dalam akta perjanjian para pihak telah menentukan, bahwa penyelesaian sengketanya dilakukan melalui jalur arbitrase, maka pengadilan negeri tidak berwenang untuk mengadilinya, jika suatu perkara yang telah dinyatakan tunduk pada proses arbitrase disidangkan oleh pengadilan, maka proses persidangannya batal demi hukum. ${ }^{6}$

\footnotetext{
${ }^{6}$ Witanto, Hukum Acara Mediasi, Alfabeta, Bandung, 2011, hal.14
} 
Dengan demikian suatu perkara yang telah disepakati oleh para pihak jika terjadi sengketa untuk diselesaikan melalui jalur arbitrase maka peradilan umum tidak berhak untuk mengadilinya dan jika tetap diadili maka keputusan tersebut batal demi hukum, hal tersebut juga telah ditegaskan dalam UU Nomor 30 Tahun 1999 yang menyatakan bahwa: pengadilan negeri tidak berwenang untuk mengadili sengketa para pihak yang telah terikat dalam perjanjian arbitrase.

Semakin banyaknya kasus sengketa bisnis diselesaikan melalui badan arbitrase hal ini menunjukkan peran badan arbitrase sangat penting dalam mendorong arus bisnis dan menyelesaikan sengketa bisnis yang member kemanfaatan bagi pelaku usaha, lebih lanjut peran penting dari badan arbitrase adalah sebagai berikut:

1. Badan arbitrase adalah salah satu alternatif penyelesaian sengketa sehingga pelaku bisnis mempunyai pilihan dalam penyelesaian sengketa bisnis dan tidak hanya tergantung dengan cara penyelesaian sengketa melalui pengadilan;

2. Badan arbitrase dapat meningkatkan iklim usaha yang sehat lintas Negara karena jika terjadi sengketa tidak diselesaikan oleh pengadilan yang dikwatirkan pengadilan akan memenangkan pengusaha local.

Untuk menjalin hubungan dagang/atau bisnis antara dua atau beberapa Negara tidak mungkin tanpa didasari prinsip-prinsip dasar yang berlaku dalam bisnis internasional, agar bisnis tersebut dapat berjalan dengan baik dan memperoleh keuntungan bagi kedua belah pihak maka para pihak harus menghormati prinsip-prinsip tersebut, dalam membuat transaksi bisnis internasional perlu diketahui dan dipahami tentang prinsip-prinsip dasar yang lazim dibuat dalam transaksi bisnis internasional yaitu :

1. Kebebasan berkontrak

2. Penawaran dan penerimaan

3. Itikad baik

4. Penggunaan istilah

5. Peralihan resiko

6. Ganti rugi (penalty)

7. Keadaan darurat (force mayor)

8. Perubahan kontrak

9. Alasan pemutusan

10. Pilihan hukum

11. Penyelesaian sengketa ${ }^{7}$

Prinsip kebebasan berkontrak berarti pada prinsipnya kedua belah pihak bebas untuk menjalin kontrak apa saja, dalam transaksi ada unsure penawaran dan permintaan yang dibuat dengan itikad baik dari kedua belah pihak, karena hubungan ini merupakan hubungan lintas Negara maka harus ada kesepahaman dalam penggunaan istilah dalam kontrak, juga harus diatur bagaimana jika terjadi resiko siapa yang harus bertanggung jawab. Kemudian bagaimana jika terjadi keadaan darurat seperti terjadinya gempa, harus ada kesepakatan dalam merubah kontrak, alasan pemutusan hubungan, hukum Negara mana yang akan dipilih untuk menyelesaikan sengketa dan bagaimana cara menyelesaikan sengketa.

Untuk masalah yang timbul dalam perdagangan internasional sangat tepat jika dilakukan melalui lembaga di luar pengadilan. sebagaimana diketahui metode

${ }^{7}$ Syahmin.AK. Hukum Kontrak Internasional, Raja Grafindo Persada, Jakarta, 2006, hal. 94. 
penyelesaian sengketa internasional secara damai dalam garis besarnya dapat dibagi dua yakni secara diplomatik (negotiation, mediation,conciliation), dan secara hukum (arbitration dan judicial settlement). Salah satu badan yang dapat menyelesaikan sengketa bisnis adalah arbitrase. Menurut Hikamahnto Juwana, Arbitration is understood as process by wich parties to dispute agree to submit their diffreneces to one or more impartial persons for a final and binding decision. ${ }^{8}$ Arbitrase adalah suatu proses untuk menyelesaikan sengketa yang diserahkan kepada orang atau suatu badan yang bersifat final dan mengikat. Orang atau badan tersebut adalah fihak independen yang diberi kewenangan untuk memutus yang bersifat final dan mengikat, sengketa yang dapat diselesaikan tersebut dapat dikategorikan menjadi 2 (dua) macam yaitu sengketa dalam ranah satu Negara (nasional) dan lebih dari satu Negara (internasional.

Suatu arbitrase disebut arbitrase internasional jika telah memenuhi beberapa hal, hal-hal tersebut adalah sebagai berikut:

Pertama, apabila para pihak yang membuat klausul arbitrase atau perjanjian arbitrase pada saat membuat perjanjian itu mempunyai tempat usaha (place of business) mereka di Negara-negara yang berbeda, kedua jika tempat arbitrase yang ditentukan di dalam perjanjian arbitrase letaknya di luar Negara tempat para pihak mempunyai tempat usaha, ketiga apabila suatu tempat di mana bagian terpenting kewajiban atau hubungan dagang para pihak harus dilaksanakan atau tempat di mana objek sengketa paling erat hubungannya (most closely connected) memang letaknya di luar Negara tempat usaha para pihak. ${ }^{9}$

Contoh pertama adalah perusahaan A memiliki usaha di Negara $X$, perusahaan B memiliki usaha di Negara Y, contoh kedua adalah ada dua perusahaan yang mempunyai usaha di Indonesia dalam perjanjiannya jika terjadi sengketa akan diselesaikan oleh badan arbitrase di Jepang, contoh yang ketiga adalah dua perusahaan yang berkantor di Negara A membangun usaha di Negara B.

Dengan demikian transaksi yang dapat diselesaikan oleh badan arbitrase internasional adalah:

1. Para pihak yang membuat klausul arbitrase atau perjanjian arbitrase pada saat membuat perjanjian itu mempunyai tempat usaha (place of business) mereka di Negara-negara yang berbeda;

2. Tempat arbitrase yang ditentukan di dalam perjanjian arbitrase letaknya di luar Negara tempat para pihak mempunyai tempat usaha;

3. Hubungan dagang para pihak harus dilaksanakan atau tempatnya di luar Negara para pihak.

Dengan kriteria sengketa bisnis internasional tersebut maka perlu diketahui badan arbitrase yang termasuk kategori badan arbitrase internasional dan bagaimana pengakuan terhadap putusan badan arbitrase internasional tersebut.

Seiring dengan semakin derasnya arus globalisasi dewasa ini yang lebih menekankan pada terjalinnya hubungan dagang baik antar dua Negara, antar kawasan maupun hubungan yang bersifat global, maka kemungkinan terjadinya sengketa dagang akan terjadi oleh karena itu sangat diperlukan adanya badan

${ }^{8}$ Hikmahanto Juwana, Dispute Resolution Process in Indonesia, IDE Asian Law Series, Japan, 2003, hal.44

9 Soedjono Dirdjosisworo, Pengantar Hukum Dagang Internasional, Refika Aditama, Bandung, 2006, hal. 112. 
penyelesaian sengketa di luar pengadilan dalam hal ini badan arbitrase yang bersifat internasional agar segala permasalahan dalam hubungan dagang tersebut dapat diselesaikan secara cepat, cermat dan terjaga kepentingan masing-masing pihak.

Di sisi lain ada permasalahan mendasar dalam penyelesaian sengketa melalui badan arbitrase internasional tersebut, permasalahannya adalah berdasarkan Article V (2) of the New York Convention that allows the court to refuse enforcement of foreign arbitration award if enforcement of the award would be contrary to the public policy of the coutry. Di sisi lain dinyatakan bahwa keputusan arbitrase adalah bersifat final dan binding sebagai tertuang dalam pasal 35 ayat (1) Model Arbitrase UNCITRAL (United Nation International Trade Law): an arbitral award, irrespective of the country in which it was made, shall be recognized as binding and shall be enforce, demikian juga ditegaskan dalam Pasal 53 UU Nomor 30 Tahun 1999 Tentang Arbitrase dan Alternatif Penyelesaian Sengketa (APS) dinyatakan bahwa terhadap putusan arbitrase tidak dapat dilakukan perlawanan atau upaya hukum apapun, dan dalam pasal 60 dinyatakan bahwa: Putusan arbitrase bersifat final dan mempunyai kekuatan hukum tetap dan mengikat para pihak.

Para pihak yang bersengketa jelas membawa penyelesaian sengketa ke badan arbitrase internasional bertujuan agar sengketa dapat segera diselesaikan dan dapat dilaksanakan, di sisi lain jelas bahwa setiap Negara memiliki kepentingan dan kebijakan nasionalnya masing-masing apalagi kebijakan suatu negara sangat tergantung sekali dengan kepentingan pemerintah yang berkuasa, sehingga ada kekawatiran bahwa keputusan badan arbitrase bisa menjadi mentah dan tidak dapat dieksekusi.

\section{METODE PENULISAN}

Metode penulisan yang penulis gunakan adalah metode penulisan Deduktif yaitu dengan cara pemaparan secara umum untuk mendapatkan kesimpulan secara khusus tentang pengakuan dan pelaksanaan putusan badan arbitrase internasional, tipe yang digunakan adalah yuridis normatif yang bersifat deskriptif analitik yaitu untuk memperoleh gambaran secara menyeluruh dan mendalam dan melakukan analisis terhadap permasalahan yang dibahas.

Untuk menjawab permasalahan maka dilakukan pengumpulan bahan hukum melalui studi dokumen (studi kepustakaan), bahan-bahan tersebut kemudian diinventarisasi dan diidentifikasi, teknis analisis dilakukan secara interpretasi, yaitu bahan hukum diinterpretasikan dan dijabarkan dengan mendasarkan pada suatu norma dan teori hukum yang berlaku, penarikan kesimpulan dilakukan dengan menggunakan metode penalaran secara deduktif.

\section{HASIL DAN PEMBAHASAN}

Salah satu fokus dalam Konvensi New York tahun 1958 adalah Convention on the Recognition an Enforcement of Foreign Arbitral Award yang ditandatangani 10 Juni 1958 di New York, konvensi ini merupakan salah satu langkah perbaikan dalam hal pengakuan dan pelaksanaan suatu keputusan arbitrase yang di buat di luar negeri khususnya bagi Negara peserta konvensi. Dalam konvensi tersebut terdapat dua persyaratan yang diperkenankan, yang pertama adalah persyaratan resiprositas (reciprocity-reservation), yang kedua adalah persyaratan komersial (commercial-reservation). 
Persyaratan pertama adalah bahwa Negara yang bersangkutan baru akan menerapkan ketentuan konvensi apabila keputusan arbitrase tersebut dibuat di Negara yang juga adalah Negara anggota konvensi New York, apabila keputusan tersebut ternyata dibuat di Negara yang bukan anggota konvensi maka Negara tersebut tidak akan menerapkan ketentuan konvensi. Persyaratan kedua adalah Negara yang telah meratifikasi Konvensi New York hanya akan menerapkan ketentuan konvensi terhadap sengketa-sengketa komersil menurut hukum nasionalnya.

Konvensi New York ini mengandung 6 pasal yang dapat diambil menjadi 5 (lima) prinsip yaitu:

1. Prinsip pertama menerapkan prinsip pengakuan dan pelaksanaan keputusan arbitrase luar negeri dan menempatkan keputusan tersebut pada kedudukan yang sama dengan keputusan peradilan nasional;

2. Prinsip kedua adalah mengakui prinsip keputusan arbitrase yang mengikat tanpa ditarik dalam keputusannya;

3. Prinsip ketiga adalah prinsip menghindari proses pelaksanaan ganda (double enforcement process);

4. Prinsip keempat adalah prinsip penyederhanaan dokumentasi yang diberikan oleh pihak yang mencari pengakuan dan pelaksanaan konvensi;

5. Prinsip kelima adalah prinsip lebih lengkap dan lebih komprehensif daripada hukum nasional pada umumnya. Hukum nasional hanya mengatur tentang pelaksanaan suatu keputusan pengadilan termasuk arbitrase, konvensi New York juga mengatur tentang pengakuan (recognition) terhadap suatu keputusan arbitrase;

Adapun ketentuan utama dari Konvensi New York ini tertuang di dalam Pasal I, III dan V yaitu:

1. Pasal 1: bahwa konvensi berlaku terhadap putusan-putusan arbitrase yang dibuat dalam wilayah suatu Negara selain daripada Negara Negara di mana pengakuan dan pelaksanaan keputusan arbitrase itu diminta dan berlaku terhadap putusan-putusan arbitrase yang bukan domestik di suatu Negara di mana pengakuan dan pelaksanaannya diminta;

2. Pasal III: mewajibkan setiap Negara peserta untuk mengakui keputusan arbitrase yang dibuat di luar negeri mempunyai kekuatan hukum dan melaksanakannya sesuai dengan hukum acara nasional di mana keputusan tersebut akan dilaksanakan;

3. Pasal V: mencantumkan alasan-alasan penolakan terhadap keputusan arbitrase internasional.

Indonesia telah meratifikasi 2 (dua) konvensi yang berhubungan dengan pelaksanaan putusan arbitrase asing yaitu:

1. Convention on the settlement of investment Dispute Between State and Nation other States, atau ICSID Convention dengan Undang-Undang Nomor 5 Tahun 1968 Tentang Persetujuan atas Konvensi tentang penyelesaian perselisihan antara Negara dan warga Negara asing mengenai penanaman modal;

2. Convention on the recognition and enforcement of foreight arbitral award atau New York Convention tahun 1958 dengan Keputusan Presiden RI Nomor 34 tahun 1981.

Di Indonesia pelaksanaan pengakuan terhadap keputusan arbitrase asing adalah berdasarkan UU Nomor 30 Tahun 1999 Tentang Arbitrase dan Alternatif penyelesaian Sengketa, dan PERMA Nomor 1 Tahun 1990, lembaga yang 
diberikan tugas untuk menangani masalah pengakuan dan pelaksanaan putusan arbitrase asing di Indonesia adalah Ketua pengadilan Negeri Jakarta Pusat.

Tahapan pelaksanaan putusan arbitrase asing terdiri dari tiga tahapan yaitu:

1. Tahap penyerahan dan pendaftaran putusan

2. Tahap pemberian eksekuator

3. Tahap eksekusi putusan

Menurut Pasal 66 UU Nomor 30 Tahun 1999 putusan Arbitrase internasional hanya diakui serta dapat dilaksanakan di wilayah hukum Indonesia apabila memenuhi persyaratan sbb:

1. Putusan arbitrase internasional dijatuhkan oleh arbiter atau majelis arbitrase di suatu Negara yang dengan Negara Indonesia terikat pada perjanjian, baik secara bilateral maupun multilateral

2. Putusan Arbitrase internasional hanya dapat dilaksanakan di Indonesia termasuk dalam ruang lingkup hukum perdagangan

3. Putusan Arbitrase internasional hanya dapat dilaksanakan di Indonesia terbatas pada keputusan yang tidak bertentangan dengan ketertiban umum (public Policy)

4. Putusan Arbitrase internasional dapat dilaksanakan setelah memperoleh eksekuatur dari Ketua Pengadilan negeri Jakarta Pusat

5. Putusan Arbitrase internasional yang menyangkut Negara Indonesia sebagai salah satu pihak dalam sengketa, hanya dapat dilaksanakan setelah memperoleh eksekuatur dari MA yang selanjutnya dilimpahkan kepada Pengadilan Negeri Jakarta Pusat

Pada dasarnya ada beberapa asas yang dijadikan landasan dalam menjalankan eksekusi putusan arbitrase asing yaitu:

1. Asas nasionalitas; untuk menentukan dan menilai apakah suatu putusan arbitrase dapat dikualifikasikan sebagai putusan arbitrase asing harus diuji menuurut ketentuan hukum nasional suatu Negara

2. Asas resiprositas; tidak semua putusan arbitrase asing dapat diakui dan dieksekusi, putusan yang dapat diakui dan dieksekusi harus memenuhi syarat sebagai berikut:

a) Kedua Negara memiliki hubungan bilateral

b) Kedua Negara terikat dengan konvensi internasional dan telah meratifikasi konvensi internasional terebut (Konvensi New York 1958).

3. Pembatasan dalam ruang lingkup hukum dagang; pengakuan dan pelaksanaan arbitrase asing hanya dapat dilaksanakan jika putusan arbitrase asing tersebut termasuk dalam ruang lingkup perdagangan

4. Putusan arbitrase internasional tidak mengganggu kepentingan umum (public policy)

Erman Radjagukguk menyatakan dalam Jurnalnya yang berjudul Implementation of the 1958 New York Convention in Several Asian Coutry: The Refusal of Foreign Arbutral Award Enforcement on The Ground Public Policy bahwa:

Some courts in Asia have manifested reluctance to rely on public police grounds to refuse recognition of foreign arbitral award. However, other courts have decided that public defense were be read as the device of protection of national interest. Public policy I nebulous concept, wich is 
different from country to country, and the subject to value of the society or the political and economic interest of the respective country. ${ }^{10}$

Jika demikian artinya beberapa pengadilan di Negara-negara Asia menolak ketertiban umum dijadikan sebagai salah satu persyaratan keputusan arbitrase internasional dapat dilaksanakan, sedangkan kebijakan masing-masing pemerintah berbeda antara satu Negara dengan Negara lain, bahkan satu pemerintahan dengan pemerintahan lainnya dalam satu Negara kemungkinan berbeda, kebijakan juga memiliki konsep yang samar. Jika seperti demikian adanya maka ada kemungkinan keputusan arbitrase internasional yang bersifat final dan binding tidak dapat dilaksanakan hanya karena tidak sesuai dengan kebijakan pemerintah dan kepentingan nasional suatu Negara.

Sedangkan di dalam Pasal 60 UU Nomor 30 Tahun 1999 tentang Arbitrase dan Alternatif penyelesaian Sengketa megatur bahwa putusan arbitrase bersifat final dan mempunyai kekuatan hukum tetap dan mengikat para pihak, ${ }^{11}$ jika suatu keputusan arbitrase internasional secara tegas dinyatakan sebagai putusan yang final dan mengikat sedangkan harus dipersyaratkan untuk dapat dilaksanakannya putusan arbitrase tidak mengganggu kepentingan/ketertiban umum menunjukkan bahwa bahwa putusan arbitrase menjadi tidak final dan mengikat karena pelaksanannya masih tergantung dengan faktor yang bersifat lebih politis bukan yuridis, hal ini akan mengakibatkan kepercayaan para pihak untuk menggunakan arbitrase sebagai jalan untuk menyelesaikan sengketa bisnis akan menjadi kecil karena pada kenyataannya putusan arbitrase belum tentu dapat dilaksanakan dan hal ini menunjukkan putusan arbitrase belum memberikan kepastian hokum bagi para pihak.

Penulis menilai bahwa ketertiban umum (public policy) tidak dapat dijadikan sebagai salah satu persyaratan untuk dapat diakui dan dilaksanakannya suatu putusan badan arbitrase internasional karena batasan ketertiban umum (public policy) antar negara belum seragam, setiap negara memiliki pemikiran dan batasan yang berbeda tentang ketertiban umum (public policy) sehingga putusan arbitrase tidak memiliki kepastian hukum dan alasan ketertiban umum (public policy) bertentangan dengan keputusan arbitrase internasional bersifat final dan binding.

\section{SIMPULAN}

Dari pembahasan tersebut maka dapat dipetik kesimpulan sebagai berikut:

1. Bahwa untuk menyelesaikan sengketa dagang dapat diselesaikan melalui jalur arbitrase berdasarkan perjanjian arbitrase kedua belah pihak sebagai salah satu model penyelesaian sengketa yang cepat, murah, putusannya bersifat final dan mengikat para pihak.

2. Ketertiban umum (public policy) tidaklah dapat dijadikan sebagai salah satu persyaratan untuk dapat tidaknya suatu keputusan badan arbitrase internasional diakui dan dilaksanakan karena bertentangan dengan keputusan arbitrase internasional yang bersifat final dan binding dan bertentangan dengan asas kepastian hukum (certainty of law).

${ }^{10}$ Erman Radjagukguk, 1 Implementation of the 1958 New York Convention in Several Asian Coutry: The Refusal of Foreign Arbutral Award Enforcement on The Ground Public Policy, Indonesia Law Review, Jakarta, 2011, hal.11

${ }^{11}$ Lihat pasal 60 UU Nomor 30 Tahun 1999 Tentang Arbitrase dan Alternatif penyelesaian Sengketa 


\section{DAFTAR PUSTAKA}

\section{Buku}

Gatot Soemartono. 2006. Arbitrase dan mediasi di Indonesia. Gramedia Pustaka Utama, Jakarta.

Hatta. 2006. Perdagangan Internasional dalam Sistem GATT dan WTO. Refika Aditama, Bandung.

Huala Adolf. 2005. Hukum Ekonomi Internasional. Raja Grafindo, Jakarta.

Munir Fuadi. 2002. Pengantar Hukum Bisnis. Citra Aditya Bakti, Bandung.

M. Yahya harahap. 2004. Arbitrase. Sinar Grafika. Jakarta.

Jimmy Joses Sembiring. 2011. Cara Penyelesaian Sengketa di Luar Pengadilan (Negosiasi, Mediasi, Konsiliasi dan Arbitrase. Visi Media.

Soedjono Dirdjosisworo. 2006. Pengantar Hukum Dagang Internasional. Refika Aditama, Bandung.

Sujud Margono. 2004. ADR dan Arbitrase. Ghalia Indonenesia. Bogor Selatan.

Syahmin.AK. 2006. Hukum Kontrak Internasional. Raja Grafindo Persada, Jakarta.

Witanto. 2011. Hukum Acara Mediasi. Alfabeta. Bandung.

\section{Jurnal}

Erman Radjagukguk. 2011. Implementation of the 1958 New York Convention in Several Asian Coutry: The Refusal of Foreign Arbutral Award Enforcement on The Ground Public Policy. Indonesia Law Review. Jakarta.

Journal of International Arbitration.2008. Survey of South East Asian Nations on the Application of the New York Convention, Netherland.

Hikmahanto Juwana. 2003. Dispute Resolution Process in Indonesia, IDE Asian Law Series. Japan.

\section{Peraturan Perundang-undangan}

Undang-Undang Nomor 5 Tahun 1968 Tentang Persetujuan atas Konvensi tentang penyelesaian perselisihan antara Negara dan warga Negara asing mengenai penanaman modal

UU Nomor 30 Tahun 1999 Tentang Arbitrase dan Alternatif Penyelesaian Sengketa (APS)

The Rule of Model UNCITRAL (United Nation Commision International Trade Law)

The Rule of Convention on the settlement of investment Dispute Between State and Nation other States (ICSID)

The Rule of Convention on the recognition and enforcement of foreight arbitral award (New York Convention tahun 1958)

Herzien Inlandsch Reglement (HIR)

$R v$ (Reglement of the Bergelijke Rechsvordering)

Keputusan Presiden RI Nomor 34 tahun 1981

PERMA Nomor 1 Tahun 1990 